\title{
Age at First Live Birth
}

National Cancer Institute

\section{Source}

National Cancer Institute. Age at First Live Birth. NCI Thesaurus. Code C19667.

The age at which a woman gave birth to her first live child. 